\title{
Carcinoma verrucoso: uma variante clínico-histopatológica do carcinoma espinocelular*
}

\section{Verrucous carcinoma: a clinical-histopathologic vari - ant of squamous cell carcinoma*}

\author{
Maurício Zanini ${ }^{1}$ \\ Marisa Homem de Mello Maciel ${ }^{3}$
}

\author{
Cláudio Wulkan²
}

Francisco Macedo Paschoal ${ }^{3}$

Resumo: O carcinoma verrucoso é uma rara e indolente forma do carcinoma espinocelular descrita por Ackerman em 1948. Sua localização preferencial é a cavidade oral. Clinicamente manifesta-se como lesão verrucosa, de progressivo e lento crescimento e bom prognóstico. 0 tratamento de escolha é a exérese cirúrgica, devendo o paciente ser regularmente acompanhado devido ao risco de recorrências.

Palavras-chave: carcinoma de células escamosas; carcinoma de células escamosas/diagnóstico; carcinoma de células escamosas/patologia.

\begin{abstract}
Verrucous carcinoma is a rare and indolent variant of the squamous cell carci noma described by Ackerman in 1948. The oral cavity is a most common site. Clinically, it presents most often as a slow-growing verrucous lesion. The prognosis is good. Treatment of choice is surger $y$. Patients require frequent reevaluation because recurrences may occur. Key words: Carcinoma, Squamous Cell; Carcinoma, Squamous Cell/diagnosis; Carcinoma, Squamous Cell/pathology.
\end{abstract}

\section{COMENTÁRIO}

O carcinoma espinocelular (CEC) surge a partir dos queratinócitos ${ }^{1}$ e apresenta diversas variantes clínicohistopatológicas, incluindo o carcinoma verrucoso (CV). Apesar de maligna, essa variante cursa com algumas características de tumor benigno. ${ }^{2}$ As características "benignas" do CV são o lento crescimento, o padrão evolutivo mais expansivo do que invasivo, e a boa diferenciação celular. ${ }^{2,3}$

A expressão carcinoma verrucoso foi definida por L.V. Ackerman ${ }^{4}$ em 1948, para caracterizar uma neoplasia verrucosa, bem diferenciada, de lento crescimento e sem tendência a metastatizar. ${ }^{5} \mathrm{O}$ CV é um CEC com baixo grau de displasia, de incidência infreqüente. ${ }^{6}$ A agressividade

\section{COMMENT}

Squamous cell carcinoma (SCC) stems from keratinocytes. ${ }^{I}$ SCC presents as several clinical and histopatho logic variants, including verrucous carcinoma (VC). Although malignant, this variant does present with charac teristics of a benign tumor. ${ }^{2}$ The "benign" characteristics of $V C$ are slow growth, a progression pattern that is more expansive than invasive, and good cellular differentiation. ${ }^{2,3}$

The expression verrucous carcinoma was defined by L.V. Ackerman in 1948 to characterize a well-differentiated verrucous neoplasia, with slow growth and without a ten dency to metastasize. ${ }^{5}$ VC is a SCC with a low degree of dys plasia, and low incidence. ${ }^{6}$ Its biological aggressiveness is

Recebido em 05.06.2002. / Received on June 05, 2002.

Aprovado pelo Conselho Consultivo e aceito para publicação em 10.09.2003. / Approved by the Consultive Council and accepted for publication on Septembrt 10, 2003.

* Trabalho realizado na Disciplina de Dermatologia Prof. Dr. Luiz Henrique Camargo Paschoal - Faculdade de Medicina do ABC, Santo André/SP. / Work done at the Prof. Dr. Luiz

Henrique Camargo Paschoal Dermatology Sector, ABC Medical Faculty, Santo André, Sao Paulo State.

Especialista em Dermatologia. Membro Efetivo da Sociedade Brasileira de Dermatologia. Monitor em Cirurgia Dermatológica e Dermatocosmetologia / Dermatology specialist. Member of the Brazilian Society of Dermatology. Supervisor of Dermatological Surgery and Dermatocosmetology

${ }^{2}$ Especialista em Dermatologia. / Dermatology Specialist.

${ }^{3}$ Professor Assistente de Dermatologia. Membro Efetivo da Sociedade Brasileira de Dermatologia / Assistant Professor of Dermatology. Member of the Brazilian Society of Dermatology.

${ }^{4}$ Chefe interino da disciplina de Dermatologia. Doutor em Dermatologia. Diretor do departamento de Cirurgia Dermatológica da Sociedade Brasileira de Dermatologia. / Interim Head of the Dermatology Section. Ph.D. in Dermatology. Head of the Dermatological Surgery Department of the Brazilian Society of Dermatology 
biológica é limitada ao local, sendo um tumor de crescimento predominante horizontal, e com maior tendência para erodir do que infiltrar. ${ }^{7}$ Tem bom prognóstico, raramente determinando metástases regionais, e não cursa com metástases a distância. ${ }^{7.8}$

O carcinoma verrucoso ou carcinoma cutâneo papilomatoso, dependendo do local, recebe várias designações; assim, na área genital, é denominado tumor de BushkeLoewenstein, na região plantar, epitelioma cuniculatum, e na boca, papilomatose oral florida, tumor de Ackerman ou $\mathrm{CV}$ oral. ${ }^{5} \mathrm{O} \mathrm{CV}$ híbrido é definido como uma lesão tumoral mista, composta predominantemente de um CV e por áreas de CEC, adquirindo os fatores prognósticos do CEC. ${ }^{8}$

Pode localizar-se na pele e em mucosas, ${ }^{7}$ sendo a cavidade oral o sítio de excelência do $\mathrm{CV}$, responsável por $70 \%$ dos casos. ${ }^{5} \mathrm{O} \mathrm{CV}$ oral é responsável por proporção que varia de 4,5 a 9\% dos CECs orais e predomina em homens acima dos 65 anos. ${ }^{6}$ Caracteriza-se clinicamente por pápula ou placa notavelmente verrucosa, branco-acinzentada e de lento crescimento, que acomete mais frequientemente a mucosa jugal, gengival e alveolar, apesar de qualquer segmento oral poder ser afetado (Figura 1). ${ }^{6}$ Infecção secundária é freqüente, podendo determinar odor desagradável e adenopatia reacional. ${ }^{1}$

Sua etiopatogenia está relacionada com carcinógenos biológicos (HPV), químicos (tabagismo) e físicos (trauma constante). Quanto ao CV oral, o tabagismo, o hábito de mascar bétel e rapé e infecção pelo papiloma vírus humano (HPV) destacam-se como os principais fatores carcinogênicos. ${ }^{2,5,6}$ Há um caso descrito da associação do líquen plano oral com o CV. ${ }^{6} \mathrm{O}$ HPV é responsabilizado por cerca de $28 \%$ dos casos, geralmente os tipos 16 e 18, mas também, 2 e 11. A carcinogênese viral provavelmente dá-se pela supressão ou mutação do gene p53, responsável pela atividade celular supressora tumoral. Entretanto, a simples evidência de uma infecção viral não é suficiente para determinar uma transformação maligna, pois a maioria dos pacientes infectados pelo HPV não desenvolve cânceres, sendo necessários cofatores. ${ }^{5}$

Como diagnóstico clínico diferencial, verificam-se CEC, verruga viral, melanoma amelanótico, histoplasmose, sífilis secundária,

Figura 1: Carcinoma verru coso oral em sua localização preferencial. limited to the localization. As it is a tumor that has predom inantly horizontal growth, it tends to erode more than infil trate. ${ }^{7}$ It has a good prognosis, which rarely causes region al metastases. It does not present with remote metastasis. ${ }^{7.8}$

Depending on its localization, verrucous carcinoma or cutaneous papillary carcinoma tends to get various des ignations. Accordingly, at the genital area it is called Bushke-Loewenstein's tumor, at the plantar region epithe lioma cuniculatum of the foot, and at the mouth oral florid papillomatosis, Ackerman tumor and/or oral VC. ${ }^{5}$ Hybrid $V C$ is defined as a mixed tumor lesion. It consists predomi nantly of $a$ VC and areas of SCC which acquire SCC prog nostic factors. ${ }^{8}$

It may be localized on the skin and in the mucosas. ${ }^{7}$ The oral cavity is the VC site par excellence, being responsi ble for $70 \%$ of cases. ${ }^{5}$ Oral VC is responsible for a propor tion of oral SCCs varying from 4.5-to-9.5\%. It predominates in men over the age of 65 years. ${ }^{6}$ It is clinically character ized by papules or a notably verrucous, white-grey plaque, with slow growth. It most often affects the jugal, gingival and alveolar mucosas, even though any oral segment can be affected (Figure 1). ${ }^{6}$ Secondary infections are frequent, and may lead to an unpleasant odor and reactional adenopathy. ${ }^{.}$

Its etiopathogenesis is related to the following car cinogens: biologic (HPV), chemical (smoking) and physical (constant trauma). As for oral VC, smoking, a habit of chewing betel and snuff and human papilloma virus infec tion (HPV), they stand out as the main carcinogenic fac tors. ${ }^{2,5,6}$ A case has been described oral lichen planus in association with VC. ${ }^{6} \mathrm{HPV}$ is responsible for roughly $28 \%$ of cases, usually types 16 and 18, but also 2 and 11. Viral car cinogenesis is most likely caused by the suppression or mutation of gene p53, which is responsible for cellular tumor suppression activity. Nevertheless, the mere evidence of a viral infection is not enough to incur a malignant transformation, because most patients infected with HPV do not develop cancer. Co-fac tors are thus necessary. ${ }^{5}$

In the clinical differen tial diagnosis, the following were observed: SSC, viral verruca, ame lanotic melanoma, histoplasmosis, secondary syphilis, Darier's dis ease, white spongy nevus and ery thematous lupus. ${ }^{6}$ Due to its high degree of differentiation, the

Figure 1: Oral verrucous carcinoma at its preferen tial Iocalization. 
doença de Darier, nevo esponjoso branco e lúpus eritematoso. ${ }^{6}$ Devido ao alto grau de diferenciação, o diagnóstico histopatológico é muito difícil. ${ }^{5}$ As alterações histopatológicas do CV incluem hiperqueratose e paraqueratose, acantose verrucosa maciça com formação de papilas alargadas em forma de clava e proeminente infiltrado inflamatório perilesional. A epiderme hiperplásica empurra a membrana basal e derme, mas a membrana basal permanece intacta. Atipia celular não é evidente, e a formação de pérolas de queratina é infreqüente. ${ }^{7}$ Mitoses e células disqueratósicas eventualmente podem ser vistas na base da lesão. ${ }^{8}$ Para que o estudo histopatológico seja confiável, a biópsia deve ser ampla e profunda a fim de demonstrar esses achados histopatológicos e permitir adequada diferenciação com o CEC e outras causas de hiperplasia pseudo-epiteliomatosa. Alguns definem o padrão histopatológico do CV como intimidadora, mas não bandida. ${ }^{5}$

$\mathrm{O}$ manejo do $\mathrm{CV}$ oral deve incluir medidas gerais como higienização oral adequada, readaptação de eventuais próteses dentárias e acompanhamento regular do paciente. $\mathrm{O} \mathrm{CV}$ pode ser considerado doença multifocal e recorrente, seja por predisposição genética ou pela permanência de fatores indutores. Assim, mesmo com a cura de um foco, poderá ocorrer recorrência da afecção em outro sítio. ${ }^{1}$

A microcirurgia de Mohs é o tratamento de escolha do CV , conferindo 98\% de cura. ${ }^{9}$ Devido à associação com HPV, a terapia com imiquimod e cidofovir é aventada. ${ }^{10}$ Radioterapia deve ser evitada em função do potencial de transformação

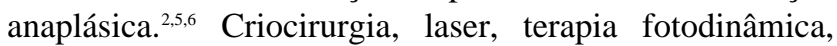
bleomicina intralesional são opções terapêuticas. ${ }^{1.5}$

\section{REFERÊNCIAS / REFERENCES}

1. MacKie RM. Epidermal skin tumors. In: Rook A, Wilkinson DS, Ebling FJG. Textbook of dermatology. London: Blackwell Science; 1998. p.1687-92.

2. Rinker MH, Fenske NA, Scalf LA, Glass F. Histologic Variants of Squamous Cell Carcinoma of the Skin. Cancer Control. 2001;8(4):354-63.

3. Cotran RS, Kumar V, Robbins SL. Patologia estrutural e functional. 4a ed. Rio de Janeiro: Guanabara Koogan; 1991. p. 197-207.

4. Ackerman LV. Verrucous carcinoma of the oral cavity. Surgery. 1948; 23: 670-8.

5. Lübbe J, Kormann A, Adams V et al. HPV-11 and HPV16 - Associated oral verrucous carcinoma. Dermatology. 1996;192:217-21.

6. Warshaw EM, Templeton SF, Washington CV. Verrucous carcinoma occurring in a lesion of oral lichen planus. Cutis. 2000;65:219-22.

7. Spiro RH. Verrucous carcinoma, them and now. Am J Surg. 1998;176:393-6.

8. Batsakis JG, Suarez P, El-Naggar AK. Proliferative ver- histopathologic diagnosis is quite difficult. ${ }^{5}$ The histopatho logic alterations of VC include hyperkeratosis and paraker atosis, soft verrucous acanthosis with formation of enlarged key-shaped papillae and prominent perilesional inflamma tory infiltrate. The hyperplasic epidermis presses against the basal membrane and dermis, but the basal membrane remains intact. Cellular atypia is not evident, and formation of keratin drops is not frequent. ${ }^{7}$ Mitosis and dyskeratotic cells might eventually be seen at the base of the lesion. ${ }^{8}$ For the histopathologic study to be reliable, the biopsy must be broad and deep in scope so as to demonstrate these histopathologic findings and allow adequate differentiation with SCC and other causes of pseudoepitheliomatous hyperplasia. Some authors define the histopathologic pat tern of VC as intimidating, but not noxious.

The management of oral VC must include general measures such as adequate oral hygiene, re-adaptation of eventual dental prostheses and regular patient reevalua tion. VC may be considered a multifocal and recurrent dis ease, whether by genetic predisposition or by the duration of inductor factors. Accordingly, even as one focus is cured, the affection might recur at another localization. ${ }^{1}$

Mohs microsurgery is the treatment of choice for $V C$, with a $98 \%$ cure rate. Due to its association with HPV, ther apy with imiquimod and cidofovir is raised as a possibili ty. ${ }^{10}$ Radiotherapy ought to be avoided as a result of the transformative potential of anaplasia. ${ }^{2,5,6}$ Cryosurgery, laser, photodynamic therapy, and intralesional bleomycin are therapeutic options. ${ }^{1,5}$

rucous leukoplakia and its related lesions. Oral Oncology. 1999;35:354-9.

9. Swanson NA, Taylor WB. Plantar verrucous carcinoma: literature review and treatment by the Mohs' chemosurgery technique. Arch Dermatol. 1980; 116(7):794-7.

10. Schell BJ, Rosen T, Rady P et al. Verrucous Carcinoma of the Foot Associated With Human Papillomavirus Type 16. J Am Acad Dermatol. 2001;45:49-55.

\footnotetext{
ENDEREÇO PARA CORRESPONDÊNCIA: / MAILING ADDRESS:

Maurício Zanini

Rua Elsa Odebrecht, 538

89021-120 Blumenau SC

Tel.: (47) 326-4458

E-mail: drzanini@ig.com.br
} 